\section{“Accepting Evolution Means You Can't Believe in God": Atheistic Perceptions of Evolution among College Biology Students}

\author{
M. Elizabeth Barnes, ${ }^{\dagger}$ Hayley M. Dunlop, ${ }^{\dagger}$ Gale M. Sinatra, ${ }^{\dagger}$ Taija M. Hendrix, ${ }^{\dagger}$ \\ Yi Zheng, ${ }^{\S}$ and Sara E. Brownell ${ }^{* *}$ \\ †School of Life Sciences, Arizona State University, Tempe, AZ 85282; ₹Rossier School of Education, \\ University of Southern California, Los Angeles, CA 90089; \$Mary Lou Fulton Teachers College \& \\ School of Mathematical and Statistical Sciences, Arizona State University, Tempe, AZ 85282
}

\begin{abstract}
Although many scientists agree that evolution does not make claims about God/god(s), students might assume that evolution is atheistic, and this may lead to lower evolution acceptance. In study 1, we surveyed 1081 college biology students at one university about their religiosity and evolution acceptance and asked what religious ideas someone would have to reject if that person were to accept evolution. Approximately half of students wrote that a person cannot believe in God/religion and accept evolution, indicating that these students may have atheistic perceptions of evolution. Religiosity was not related to whether a student wrote that evolution is atheistic, but writing that evolution is atheistic was associated with lower evolution acceptance among the more religious students. In study 2, we collected data from 1898 students in eight states in the United States using a closed-ended survey. We found that $56.5 \%$ of students perceived that evolution is atheistic even when they were given the option to choose an agnostic perception of evolution. Further, among the most religious students, those who thought evolution is atheistic were less accepting of evolution, less comfortable learning evolution, and perceived greater conflict between their personal religious beliefs and evolution than those who thought evolution is agnostic.
\end{abstract}

\section{BACKGROUND}

While evolution is considered a foundational component of biology (American Association for the Advancement of Science, 2011; Brownell et al., 2014), it remains controversial in American society, with roughly half of individuals rejecting human evolution (Miller et al., 2006; Gallup, 2019). Although there are aspects of evolutionary theory that are mostly accepted by college biology students (for instance, adaptation by natural selection), studies show that college biology students struggle to accept human evolution and the common ancestry of life on Earth. Almost half of the general college population does not accept that all of life evolved (Barnes et al., 2008), and in one study, more than a quarter of upper-level biology students did not accept that all of life on Earth is related (Ingram and Nelson, 2006). Given the foundational position of evolution in biology, it is particularly surprising that college biology majors struggle with accepting these aspects of evolution. Research indicates that individuals are less likely to accept evolution when they are religious and when they do not have an understanding of the nature of science, which can be common among college biology students (Barnes and Brownell, 2017; Dunk et al., 2017; Scharmann, 2018; Nelson et al., 2019).
Ross Nehm, Monitoring Editor Submitted Jun 3, 2019; Revised Mar 16, 2020: Accepted Apr 10, 2020

CBE Life Sci Educ June 1, 2020 19:ar21

DOI:10.1187/cbe.19-05-0106

*Address correspondence to: Sara E. Brownell (sara.brownell@asu.edu)

(c) 2020 M. E. Barnes et al. CBE-Life Sciences Education () 2020 The American Society for Cell Biology. This article is distributed by The American Society for Cell Biology under license from the author(s). It is available to the public under an Attribution-Noncommercial-Share Alike 3.0 Unported Creative Commons License (http://creativecommons.org/licenses/ by-nc-sa/3.0).

"ASCB $\AA^{\circledR}$ " and "The American Society for Cell Biology $\circledR^{\circledR}$ are registered trademarks of The American Society for Cell Biology. 


\section{Why Is Religiosity Negatively Correlated with Evolution Acceptance in the United States?}

Many studies in the United States show that individuals are less likely to accept evolution when they are more religious ( $\mathrm{Ha}$ et al., 2012; Glaze et al., 2014; Rissler et al., 2014; Barnes et al., 2017a, 2019; Dunk et al., 2017). ${ }^{1}$ Christianity is the predominant religion in the United States; about $90 \%$ of those who identify as religious self-report they are Christian (Pew, 2015). Thus, when considering the relationship between religiosity and evolution acceptance in the United States, we are largely considering the relationship between Christian religiosity and evolution acceptance.

Christian religiosity is associated with lower evolution acceptance, in part because some Christian religious beliefs and Christian religious cultures are perceived to be in direct conflict with evolution (Scott, 2005; Numbers, 2006; Hill, 2014; Kahan and Stanovich, 2016; Saad, 2017). For instance, it is the cultural norm to be opposed to evolution within some Christian denominations (Numbers, 2006). Further, a Christian's beliefs about creationism and evolution can impact that person's acceptance and belonging within their Christian community (Barnes et al., 2017b; Barnes and Brownell, 2018), which may lead some individuals to reject evolution. Several research studies show that the beliefs of one's family and church members are major predictors of evolution acceptance (Winslow et al., 2011; Hill, 2014; Barnes et al., 2017a), which supports the notion that those Christian cultures that are anti-evolution are a barrier for their members to fully accept evolution.

In addition to anti-evolution cultural norms, Christians can also hold a literal interpretation of their Bible that can lead them to reject evolution. If one takes the creation stories in the Bible literally, one would have to believe that species were created separately from one another, which is in direct conflict with a central tenet of evolution that all of life shares a common ancestor. Thus, literal interpretations of the Bible have led some Christians to adopt anti-evolution beliefs. For instance, young Earth creationism is the belief that species were created in their present form 6000-10,000 years ago, while others adopt old Earth creationism and believe that species were created in their present form over millions of years. Other Christians may adopt a mix of special creationism and evolution in which groups such as birds, mammals, and fish were created separately from one another by God, but then subsequently evolved (creationism with some evolution) or that all of life evolved, except for humans who were created separately by God (humans-only creationism; Yasri and Mancy, 2016). All of these variants of special creationism rely on a literal interpretation of the Bible to some extent (Yasri and Mancy, 2016). However, there are many Christians who do not believe special creationism and instead accept evolution.

\footnotetext{
${ }^{1}$ Religiosity is a multifaceted trait that is characteristically variable within and across religious denominations due to vastly different practices and cultures. Despite this variation in religion, there are shared characteristics of people's religious lives that psychologists of religion use to measure the extent to which someone is religious, and we define religiosity in this article similarly to how psychologists of religion often define religiosity. We define religiosity as the extent to which one participates in religious activities such as prayer and service attendance (i.e., church attendance) in combination with the extent to which one believes one's religious identity is important to one's identity (Cohen et al., 2008).
}

There are many ways that individuals, including scientists and religious leaders who are Christian, report they have reconciled their religious beliefs with an acceptance of evolution (Miller, 1999; Collins, 2006; Tharoor, 2014). Those who adopt a deistic evolution view may think that their God started the universe but did not have a specific goal or purpose for evolution (Yasri and Mancy, 2016). Those who adopt a theistic evolution or interventionist evolution perspective may believe that their God created life with a goal or that their God actively intervenes in evolution (Miller, 1999; Collins, 2006; Yasri and Mancy, 2016). The main difference between these views is the extent to which one believes one's God is involved in evolution (Yasri and Mancy, 2016). The commonality in these views is that all include a belief that life on Earth shares a common ancestor (Miller, 1999; Collins, 2006; Yasri and Mancy, 2016). However, are these views in which God is involved in evolution compatible with the scientific theory of evolution? It depends on whether one believes that science is, by nature, atheistic.

\section{Is Evolution Atheistic or Agnostic?}

Supernatural entities like God are often described as having characteristics such as omniscience and omnipotence that make them unfalsifiable and therefore unable to be examined through scientific means (Popper, 1959). This idea that science cannot be used to prove or disprove the existence of the supernatural has been called the bounded nature of science and assumes that science is limited to investigating natural phenomena using natural explanations (Southerland and Scharmann, 2013; Nelson et al., 2019). Although there are vocal scientists who believe that science can disprove the existence or influence of God (Harris, 2005; Dawkins, 2009; Coyne, 2015; Krauss, 2015), the majority of scientists and philosophers of science agree that science does not address supernatural entities (Barbour, 1990; Miller, 1999; Collins, 2006; Ecklund and Park, 2009; Ecklund et al., 2011; Gould, 2011). To make a claim about the existence or nonexistence of a supernatural entity is unscientific according to the bounded nature of science. Therefore, rather than being anti-theistic, science can be considered non-theistic (Nelson et al., 2019; Smith, 1994).

Whether someone understands and accepts the bounded nature of science will determine whether he or she considers interventionist evolution, deistic evolution, and theistic evolution as full acceptance of evolution. If one does not understand or subscribe to the bounded nature of science, then one might conclude that evolution is atheistic, which would exclude these views as acceptance of evolution. However, if one understands and subscribes to the view of the bounded nature of science, then one may conclude that evolution is agnostic rather than atheistic and thus consider views that both include God and do not include God as acceptance of evolution. According to individuals with these views, acceptance of evolution is not contingent on a view of God, because they have aligned their religious view with science, not the other way around. The term "agnostic" was coined by Thomas Henry Huxley (who was a strong advocate of evolution when Darwin published the Origin of Species) to describe what he believed was the most scientific view of nonscientific matters (Huxley and Huxley, 1900). Huxley wrote: 
Agnosticism is of the essence of science ... It simply means that [we] shall not say [we] know or believe that which [we] have no scientific grounds for professing to know or believe ... Consequently, agnosticism puts aside not only the greater part of popular theology, but also the greater part of anti-theology ... Agnosticism simply says that we know nothing of what may be beyond phenomena. (Huxley, 1884)

We advocate that the term "agnostic" is a useful characterization of evolutionary theory, because it is most aligned with the bounded nature of science, and it is fitting that this term is already associated with evolution in the history of science.

Considering the bounded nature of science and characterizing evolutionary theory as agnostic rather than atheistic clarifies that a Christian student who believes in God can indeed accept evolution. From our perspective, as well as that of many others, a student who is atheist, agnostic, Christian, Hindu, Muslim, Jewish, or Buddhist can accept evolution (Smith, 1994; Scott, 2005; Southerland and Scharmann, 2013). If evolution is by nature agnostic, then what characterizes a student's acceptance of evolution is not whether they believe in God, but whether they accept the scientific consensus on evolution in which species change through time and life on Earth shares a common ancestor. However, many students may not be aware of the bounded nature of science, and they may perceive that evolution is atheistic rather than agnostic.

\section{College Biology Students May Think Evolution Is Atheistic and This Could Lead to Lower Evolution Acceptance}

Past qualitative data from several studies indicate that students may have the conception that evolution is atheistic, but we do not know the degree to which this perception exists among biology students. Winslow et al. (2011) interviewed senior Christian biology majors. Many quotes from students who changed from special creationism to acceptance of evolution indicated that they first perceived evolution was atheistic, but then changed to believing that evolution and Christianity could be compatible before they accepted evolution. In a study by Scharmann and Butler (2015), the researchers asked nonmajor biology students at a community college to journal about their experiences learning evolution. In the paper, the researchers presented many quotes in which students indicated they did not know that they could believe in God and accept evolution. In a past study in which our research team implemented evolution instruction that was designed to be culturally competent for religious students, we asked students what they appreciated about the instruction and many religious and nonreligious students wrote that that they did not previously know that someone could believe in God and accept evolution (Barnes et al., 2017). Brem et al. (2003) found that $88 \%$ of students perceived it was harder for others to "believe in a supreme being" if they accepted evolution, which suggests they might think that evolution is atheistic, but the researchers did not ask students if one could believe in a supreme being and accept evolution. These data warrant exploring the hypothesis that atheistic perceptions of evolution may be prevalent and may influence acceptance of evolution among college biology students. If atheistic perceptions of evolution are prevalent, then this pinpoints a needed area for instructors to address when teaching evolution, particularly if this perception is related to worse affective evolution education outcomes among highly religious students who are most at risk for rejecting evolution.

\section{RESEARCH QUESTIONS}

Our main research aim was to explore students' atheistic perceptions of evolution and whether these perceptions were related to students' evolution acceptance, perceived conflict between religion and evolution, and comfort learning evolution. We conducted an exploratory study to identify what religious ideas students think they have to reject in order to accept evolution and if writing that evolution is atheistic is associated with lower levels of evolution acceptance. Then, in a subsequent study we explored the prevalence of atheistic perceptions of evolution and whether atheistic perceptions were related to lower evolution acceptance, greater perceived conflict between religious beliefs and evolution, and less comfort learning evolution. We outline here each of our research questions and hypotheses for each study.

\section{Study 1: What Religious Ideas Do Students Think One Has to Reject in Order to Accept Evolution? If Students Write That Evolution Has to Be Atheistic, Is This Associated with Lower Evolution Acceptance?}

Although prior qualitative research has shown that students can have concerns about their ability to maintain their religious beliefs and accept evolution (Barnes et al., 2017b; Winslow et al., 2011), we do not know exactly what religious ideas college biology students think someone would have to reject to accept evolution. Students could have a wide variety of perceptions, including that someone has to completely reject a belief in God in order to accept evolution, which could negatively affect religious students' acceptance of evolution. Thus, in study 1 , we asked students to answer an open-ended question about the religious ideas that would have to be rejected for someone to accept evolution. We hypothesized that some students would say that it is necessary to reject a belief in God in order to accept evolution, and we also hypothesized that highly religious students who wrote that evolution is atheistic would accept evolution less than highly religious students who did not. This exploratory study allowed us to investigate potential student perceptions and their association with student levels of evolution acceptance.

\section{Study 2: What Proportion of College Biology Students Think That Evolution Is Atheistic?}

In study 2, we wanted to explore atheistic perceptions of evolution in a large number of biology classes across the nation using a closed-ended survey. The decision to use a closed-ended survey in study 2 was a natural progression of the research aims; in study 1 , we were able to identify students who thought to write about an atheistic perception of evolution, but there may have been a greater number of students who had this perception but just did not choose to write about it. A closed-ended survey allowed us to determine the prevalence of atheistic perceptions of evolution among students in college biology courses, because each student had to choose whether they had an atheistic perception of evolution. Further, a closed-ended survey allowed us to give students the option to choose between an atheistic perception of evolution and an agnostic perception of evolution, something they were not able to do with the open-ended question in study 1 . For study 2 , we hypothesized that a significant 
proportion of students would have an atheistic perception of evolution.

\section{Study 2: Do Highly Religious Students Accept Evolution Less, Perceive More Conflict between Their Religious Beliefs and Evolution, and Experience More Discomfort when They Think Evolution Is Atheistic?}

We aimed to explore whether atheistic perceptions of evolution among highly religious students were associated with evolution education variables. In addition to being less accepting of evolution, we hypothesized that highly religious students who have an atheistic perception of evolution would perceive more conflict between their religious beliefs and evolution and feel less comfortable while learning evolution. This is potentially important, because students who are less accepting of evolution and perceive more conflict between their religious beliefs and evolution may be unlikely to use evolution in their thinking about science in the future or to pursue further learning about evolution beyond what is required of them in the classroom. Further, students who are less comfortable in their learning environments may have more trouble learning the content of evolution and/or moving toward a more positive attitude toward evolution. Indeed, in group settings, student comfort has been shown to be related to student outcomes such as persistence in a program and final grades in a course (Micari and Drane, 2011; Eddy et al., 2015; Theobald et al., 2017).

\section{STUDY 1}

\section{Study 1 Methods}

We surveyed students from 10 introductory-level majors and nonmajors biology courses at a large public research-intensive university in the southwestern United States in which the population is moderately religious on average (Barnes et al., 2019). Students were surveyed in the last 2 weeks of their courses and all courses included evolution instruction. Instructors of the courses offered students extra credit as an incentive to complete the survey. The email recruitment told students that they would be filling out a survey about their conceptions of evolution. Students were surveyed at the end of the semester after most evolution instruction had occurred. The university's Institutional Review Board (\#3910) approved all procedures.

Measures. We asked students to self-report major, race/ethnicity, and gender. We obtained students' college grade point averages (GPAs) from the university registrar.

We used two separate measures of evolution acceptance that served different purposes. A recent study found that results in evolution education studies can be different when using the respondents' own definition of evolution acceptance as opposed to when the researchers define evolution acceptance for the respondents (Barnes et al., 2019). One measure let students define evolution acceptance for themselves (self-defined measure) and asked students to rate on a scale from 0 to 100 the extent to which they accepted evolution; this is similar to measures used in other foundational studies in evolution education (Bishop and Anderson, 1990; Sinatra et al., 2003; Hermann, 2012). The second measure we used is a published instrument called the Inventory of Student Evolution Acceptance (I-SEA) that predefines evolution acceptance for the respondents as the extent to which they agree with 24 items on a five-point Likert scale (Nadelson and Southerland, 2012). The I-SEA has three subscales: acceptance of microevolution (e.g., "natural selection is a reasonable explanation that describes the ways in which groups of organisms have changed over time"), acceptance of macroevolution (e.g., "I think that new species arise from ancestral species"), and acceptance of human evolution (e.g., "like other organisms, the human species is a result of evolution from an ancestral group"). We chose to use the I-SEA instead of other published instruments (e.g., Measure of Acceptance of the Theory of Evolution (MATE) or Generalized Acceptance of EvolutioN Evaluation (GAENE); Rutledge and Warden, 1999; Smith et al., 2016), because the I-SEA disaggregates student acceptance of microevolution, macroevolution, and human evolution, each of which has been shown to be a different construct (Nadelson and Southerland, 2012; Sbeglia and Nehm, 2019) and to produce different research findings (Barnes et al., 2019; Sbeglia and Nehm, 2019). Further, there are claims that the I-SEA addresses many limitations of other evolution acceptance instruments (Barnes et al., 2019; Sbeglia and Nehm, 2019). In this current study, the internal reliability of the three subscales of the I-SEA were high (microevolution acceptance, $\alpha$ $=0.90$; macroevolution acceptance, $\alpha=0.89$; human evolution acceptance, $\alpha=0.93$ ).

We measured student religiosity using a previously published scale (Cohen et al., 2008). The measure consists of eight items that measure two important dimensions of religiosity: the intrinsic strength of one's religious identity (e.g., "I consider myself a religious person") and participation in religious activities (e.g., "I attend religious services regularly") and are similar to other common measures used both in studies of religion (Dingemans and Van Ingen, 2015; Ecklund et al., 2018) and studies of evolution acceptance (Rissler et al., 2014; Dunk et al., 2017). Cronbach's alpha for this measure in this study was high $(\alpha=0.96)$.

To explore what religious ideas students perceived someone would have to reject in order to accept evolution, we created an open-ended item to elicit students' open thinking. We asked students to "List any religious ideas you think a person has to reject for them to accept evolution. List as many things as you can think of." Before data collection, a researcher (M.E.B.) conducted think-aloud interviews on the survey item with five college biology students in which the students were instructed to repeat the survey prompt in their own words so that the researchers could determine whether the prompt was being interpreted correctly by students (Willis, 2004). The prompt was revised based on student feedback to increase the likelihood that the prompt was being understood by students in the way the authors intended, which helped to establish the construct validity of the question (García, 2011; Eignor, 2013).

Analyses. To explore what religious ideas students perceived someone would have to reject in order to accept evolution, we coded students' open-ended responses to the prompt "List any religious ideas you think a person has to reject for them to accept evolution. List as many things as you can think of." using inductive content analysis (Cho and Lee, 2014). Inductive methods were used, because this specific question had never been explored among students, and we did not want to bias our findings, so we let themes emerge from the data. A rubric was created by M.E.B. that described the identified themes, and the 
rubric was then used by M.E.B. to categorize all student responses. Next, the rubric was used independently by H.M.D. to categorize a random subset $(10 \%)$ of student responses that had already been coded by M.E.B. Cohen's kappa was calculated using the codes from the two researchers, and a kappa statistic of greater than 0.90 was reached for all codes, indicating very high interrater reliability (Landis and Koch, 1977).

We used multiple linear regressions to determine whether writing that evolution is atheistic was related to lower levels of evolution acceptance depending on student religiosity level. To control for potentially confounding variables, we added student GPA, major (biology or non-biology), gender, and race/ethnicity to our regressions. For scores from each evolution acceptance instrument (self-defined evolution acceptance, microevolution acceptance, macroevolution acceptance, and human evolution acceptance) we used the following regression equation: evolution acceptance $\sim$ gpa + major + gender + race/ethnicity (white as a reference) + religiosity + atheistic evolution perception + religiosity*atheistic evolution perception. After each regression model was fit to the data, we performed full regression diagnostics to make sure the statistical assumptions of this method (i.e., the error term follows an independent identical normal distribution with constant variance) were adequately met and that the fitted linear model results adequately represent the data (i.e., checking linearity, multicollinearity, and influential points; Kutner et al., 2005). All results we report in the Results sections have passed the full diagnostics.

\section{Study 1 Results}

Population and Descriptive Data. Of the 1800 introductory biology students sent a survey link, 1081 completed the survey (60\% response rate). Of these students, $58 \%$ were female and $42 \%$ were male; $50 \%$ were White, $13 \%$ were Asian, $17 \%$ were Hispanic, 4\% were Black/African American, 11\% were mixed race/ethnicity, and $5 \%$ of students did not answer the question about race/ethnicity. Seventy-one percent of students were biology majors and the average end-of-semester GPA for these students was 3.35. This is similar to the overall student population at this institution, although the Asian students are slightly overrepresented in our sample compared with the broader population at the university, but that may be because Asian students tend to be overrepresented in biology (National Science Foundation, National Center for Science and Engineering Statistics, 2017).

Students reported an average of 80 out of 100 on the $0-100$ self-defined evolution acceptance measure. Student scores for each subscale of the I-SEA were calculated by aggregating scores from questions on each of the subscales and then dividing the aggregate score by the number of questions on that scale so that the final scores for each subscale represented students' average agreement with microevolution, macroevolution, and human evolution questions (1-5; strongly disagree-strongly agree). On average, students more than "agreed" with microevolution $(\mathrm{M}=4.20, \mathrm{SD}=0.70)$ and macroevolution $(\mathrm{M}=4.01$, $\mathrm{SD}=0.78$ ), but scored between "neutral" and "agree" on human evolution ( $M=3.89, \mathrm{SD}=0.92)$. Student religiosity scores were calculated by aggregating scores from the two religiosity questions and dividing that score by two so that a student's final score represented average agreement with the religiosity questions (1-5; strongly disagree-strongly agree). This student population was moderately religious $(\mathrm{M}=2.95, \mathrm{SD}=1.24)$.

\section{Study 1 RQ 1: What Religious Ideas Do Students Think One Has to Reject in Order to Accept Evolution?}

We identified 14 subthemes in students' responses that fell into two broader themes that we report here: biblical literalism and God/religion. A list of subthemes and their descriptions can be found in Section 1 of the Supplemental Material.

Biblical Literalism. Forty-one percent of students correctly reported that to accept evolution, a person would have to reject a literal interpretation of Judeo-Christian religious texts. Most often, these students wrote that a person could not believe in the literal interpretation of stories in the Judeo-Christian Bible, such as the seven-day creation story of Genesis, Noah's Ark, and the human creation story of Adam and Eve, if that person were to accept evolution (Table 1). Most biologists would agree that one would not be able to believe literally in many of the creation stories in the Judeo-Christian Bible to accept evolution.

God/Religion. Almost half of students (48\%) indicated that a person would have to be an atheist to accept evolution. These students thought one would have to reject a belief in a God/ religion broadly if that person were to accept evolution. Students in this category most often indicated that a person would have to reject the existence of God or reject that God was responsible for the creation of life if that person were to accept evolution (Table 1). We call this an atheistic perception of evolution (Smith, 1994; National Academy of Sciences, 1998, 2008; Gould, 2011; Scharmann, 2018; Nelson et al., 2019).

Point-biserial correlations revealed that different levels of student religiosity were not related to whether the student perceived evolution as atheistic $\left(r_{\mathrm{pb}}(1081)=0.03, p=0.40\right)$. This suggests that perceiving evolution as atheistic is prevalent among highly religious students as well as students who score low on religiosity. Higher religiosity was negatively correlated with a student identifying biblical literalism as necessary to reject for one to accept evolution $\left(r_{\mathrm{pb}}(1081)=-0.17\right.$, $p<0.001)$.

\section{Study $1 \mathrm{RQ} 2$ : If students write that evolution has to be atheistic, is this associated with lower evolution acceptance?}

Using multiple linear regressions and controlling for GPA, whether the student was a biology major, gender, and race/ ethnicity we found a strong negative main effect of religiosity on all evolution acceptance measures (self-defined evolution: $\beta=-0.50, p<0.001$; microevolution: $\beta=-0.42, p<0.001$; macroevolution: $\beta=-0.48, p<0.001$; human evolution: $\beta=$ $-0.56, p<0.001$ ), indicating that religious students had lower levels of evolution acceptance. We also found a negative main effect of perceiving evolution as atheistic on all evolution acceptance measures (self-defined evolution: $\beta=-0.22, p<0.001$; microevolution: $\beta=-0.13, p<0.001$; macroevolution: $\beta=$ $-0.14, p<0.001$; human evolution: $\beta=-0.13, p<0.001$ ), indicating that students who wrote that evolution is atheistic had lower levels of evolution acceptance.

Importantly, the interaction between religiosity and writing that evolution is atheistic was significant for all evolution acceptance measures (self-defined evolution: $\beta=-0.58, p<0.001$; microevolution: $\beta=-0.33, p<0.001$; macroevolution: $\beta=$ $-0.24, p=0.001$; human evolution: $\beta=-0.17, p=0.02$ ), 
TABLE 1. General themes identified from student responses to the open-ended prompt "List any religious ideas you think a person has to reject for them to accept evolution. List as many things as you can think of." and example student responses for each theme ${ }^{a}$

\begin{tabular}{|c|c|c|c|c|c|}
\hline Theme & Description & Example excerpts & $\begin{array}{c}\% \text { religious } \\
\text { students }\end{array}$ & $\begin{array}{c}\% \text { nonreligious } \\
\text { students }\end{array}$ & $\begin{array}{c}\text { Total \% } \\
\text { of students }\end{array}$ \\
\hline Biblical literalism & $\begin{array}{l}\text { Student indicates one must reject } \\
\text { a literal interpretation of } \\
\text { biblical/religious stories in } \\
\text { order to accept evolution. } \\
\text { Prevalent subthemes include: } \\
\text { Noah's ark, Adam and Eve, } \\
\text { special creationism, and } \\
\text { young Earth creationism. }\end{array}$ & $\begin{array}{l}\text { "[A person has to reject the] } \\
\text { Adam and Eve story from the } \\
\text { Bible." } \\
\text { "[A person has to reject] the } \\
\text { literal interpretation of the } \\
\text { Bible stating that the earth } \\
\text { was created by God several } \\
\text { thousand years ago." } \\
\text { "[A person has to reject] Adam } \\
\text { and Eve and Noah’s ark." }\end{array}$ & 32.8 & 47.7 & 40.8 \\
\hline $\begin{array}{l}\text { God/religion } \\
\text { "atheistic definition" }\end{array}$ & $\begin{array}{l}\text { Student indicates that one must } \\
\text { reject religion generally, all } \\
\text { religious ideas, and/or the } \\
\text { existence or influence of a } \\
\text { God in order to accept } \\
\text { evolution. }\end{array}$ & $\begin{array}{l}\text { "[A person has to reject] the } \\
\text { existence of a Creator of } \\
\text { Earth or life or any form of a } \\
\text { god or gods." } \\
\text { "[A person has to reject] } \\
\text { Christianity and any other } \\
\text { religion." } \\
\text { "[A person has to reject] the } \\
\text { concept of God if they want } \\
\text { to accept evolution." }\end{array}$ & 49.0 & 47.2 & 48.0 \\
\hline
\end{tabular}

\begin{abstract}
aReligious students are those who scored higher than "neutral" on average on the religiosity questions, and nonreligious students are those who scored neutral or below
\end{abstract} on average on the religiosity questions.

indicating that writing that evolution is atheistic was most negatively associated with evolution acceptance when the student was a more religious student. For instance, the least religious student who is a biology major with a 4.0 GPA is predicted to score $100 / 100$ on the self-defined evolution acceptance instrument regardless of whether they wrote that evolution is atheistic. However, the same student with a high religiosity score is expected to score $41 / 100$ points on the self-defined evolution acceptance measure if they wrote that evolution is atheistic as opposed to $75 / 100$ points if they did not write that evolution is atheistic. Figure 1 illustrates this interaction effect of student religiosity and writing that evolution is atheistic on evolution acceptance scores from all four evolution acceptance measures. For those interested in the results of race/ethnicity, gender, GPA, and major on all outcome variables, full regression tables with omnibus statistics are available in Section 2 of the Supplemental Material.

\section{Study 1 Conclusions and Limitations}

In our exploratory study 1 , a large percentage of college biology students wrote that evolution is atheistic, and this was prevalent among both religious and nonreligious students. Further, we found that writing that evolution is atheistic was associated with lower levels of evolution acceptance, particularly among the most religious students. However, using an open-ended response item may have caused us to misestimate the prevalence of atheistic perceptions. First, students could have had an atheistic perception of evolution but did not think to write about it; this would lead us to underestimate the number of students with an atheistic perception of evolution. Second, students could have been conflating the ideas of "God" or "religion" with "special creationism" in their responses, and this would lead us to overestimate the number of students with atheistic perceptions of evolution. Thus, to estimate the rate of atheistic perceptions of evolution, we developed a closed-ended survey in study 2 that asked students to choose whether evolution is atheistic or agnostic.

\section{STUDY 2}

\section{Study 2 Methods}

We surveyed students from 12 college biology courses at eight different institutions in Utah, New York, Alabama, North Carolina, Hawaii, Arizona, and Wisconsin. Students were surveyed at the end of their courses, and all courses included evolution instruction. A summary of the courses recruited for this study can be found in the Results section. The research team sent emails to the instructors of the courses asking them to disseminate the survey link to their students after the students had been taught evolution. Instructors offered extra credit to students who completed the survey. The email recruitment told students that they would be filling out a survey about their conceptions of evolution. Our university's Institutional Review Board (\#8191) approved all procedures.

Measures. We asked students to self-report major, race/ethnicity, and gender.

We used similar instruments to measure evolution acceptance in study 2 as in study 1 . We asked students on a scale of 0-10 "To what extent do you think evolution is true?," and we used the I-SEA to measure students' acceptance of microevolution $(\alpha=0.88)$, macroevolution $(\alpha=0.86)$, and human evolution $(\alpha=0.92)$.

We chose to use only four religiosity items ("I consider myself a religious person," "I believe in God," "I consider myself a spiritual person," and "I attend religious services regularly") from study 1 to measure the extent to which a student was religious in study 2 . We reduced this measure to four items in 
a.)

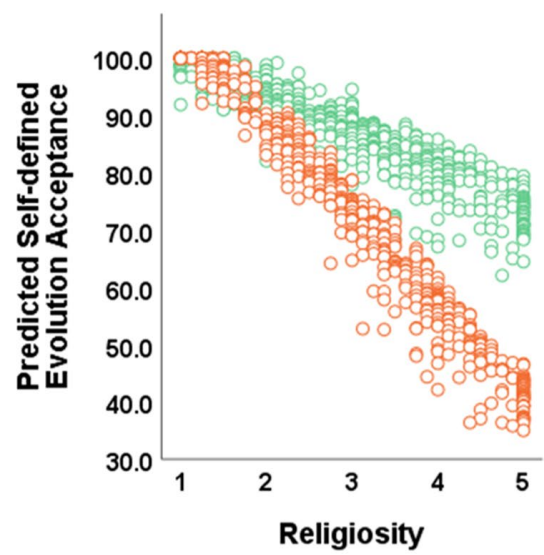

c.)

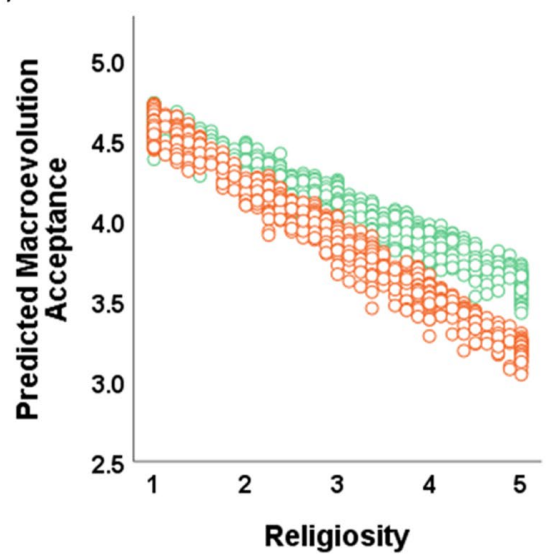

b.)

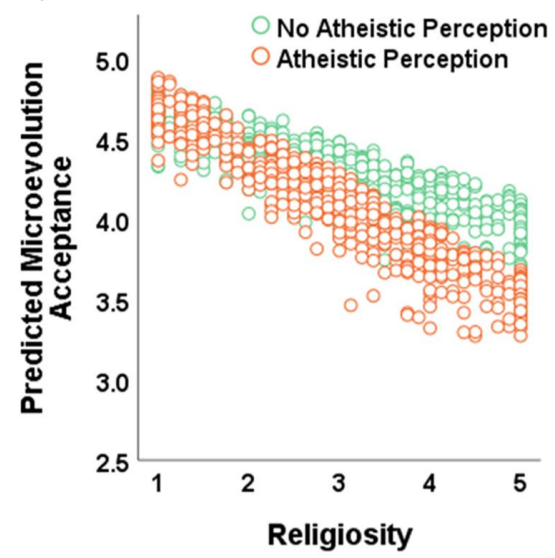

d.)

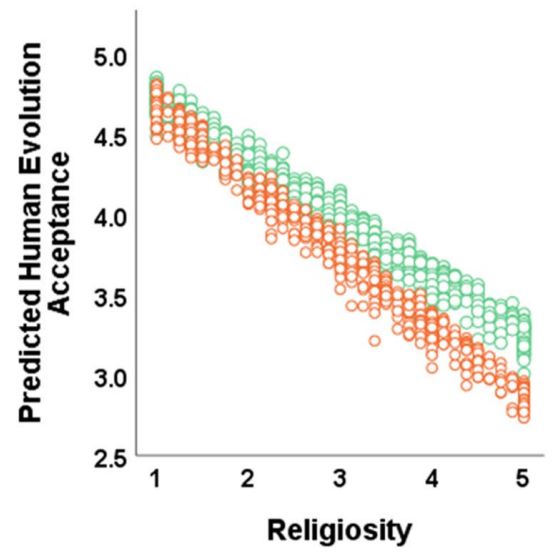

FIGURE 1. Unstandardized predicted values from regression models predicting evolution acceptance scores plotted against student religiosity and labeled by whether the student indicated an atheistic perception of evolution. All predicted values control for student GPA and whether the student was a life science major: evolution acceptance GPA + major + gender + race/ethnicity (white reference) + religiosity + atheistic evolution perception + religiosity*atheistic perception. All interactions depicted for (a) self-defined evolution acceptance, (b) microevolution acceptance, (c) macroevolution acceptance, and (d) human evolution acceptance were statistically significant $(p<0.05)$.

The list of views includes young Earth creationism, old Earth creationism, creationism with some evolution, humansonly creationism, interventionist evolution, theistic evolution, deistic evolution, agnostic evolution, and atheistic evolution. We used this measure to capture the students' personal views on evolution and religion, but also adapted the prompt of the instrument to create a second item that could capture whether students perceived evolution as atheistic.

Students were first presented with descriptions of each view and asked, "Please indicate which of the following items most closely represents your personal view, based on your personal opinion." Thus, we were able to capture students' personal views on religion and evolution. Next, we presented students with the same options and told them, "Choose what most closely represents the scientific view, according to evolution," which gave the students the opportunity to choose whether they thought atheistic evolution or agnostic evolution is the most accurate description of evolution. The procedures for adapting and validating the instruments in their entirety are available in Section 3 of the Supplemental Material.

We also created two new instruments (see Section 4 of the Supplemental Material for development and validation of these measures). The first instrument measures students' perceived conflict between their religious beliefs and evolution and has four items (e.g., "How much conflict do you perceive between your personal religious beliefs and evolution?"). Students were asked to select from 0 (none at all) to 10 (a lot) for each of these items. Unlike other instruments in which the respondent

study 2, because the bivariate correlation between scores using the four and eight items was extremely high $(r=0.89)$. Further, we wanted to reduce survey fatigue among students in our studies, and in think-aloud interviews some items on the full religiosity survey were confusing for nonreligious students (i.e., "I practice the requirements of my religion or faith"). Thus, eliminating these items increased the content validity of the measure for nonreligious students. The internal reliability of the four items was high $(\alpha=0.90)$.

To determine whether students perceived evolution as atheistic or agnostic, we adapted a published instrument originally created to categorize the views that students have on the relationship between religion and evolution (Yasri and Mancy, 2016). This instrument was not published when the data from study 1 were collected. The instrument lists different views on the relationship between religion and evolution and asks students to choose among the views in a closed-ended survey (Table 2). can only choose a binary option (Nehm et al., 2009), this range allowed us to detect several levels of conflict. This instrument had high internal reliability in this study $(\alpha=0.91)$. The second instrument measures how comfortable students felt while learning evolution and has eight items (e.g., "I felt comfortable while I was learning evolution"). Students were asked to answer on a six-point Likert scale from strongly disagree to strongly agree. This instrument had high internal reliability in this study $(\alpha=0.91)$. No previously developed instruments existed at the time of the study to measure either perceived conflict or comfort learning evolution. These instruments are available in their entirety along with the procedures for development and validation in Section 4 of the Supplemental Material.

Analyses. Although it was not our main research aim, our research design allowed us to examine the percentage of college biology students who believe that life shares a common ancestor. Because these data have never been collected among 
TABLE 2. Options students were given for their personal view of evolution and then what they thought most closely represented the scientific view of evolution

\begin{tabular}{|c|c|}
\hline Choice & Description presented to student \\
\hline Young Earth creationism & $\begin{array}{l}\text { All forms of life were first brought into being in their present form by God } 6000-10,000 \text { years ago at the same } \\
\text { time. }\end{array}$ \\
\hline Old Earth creationism & All forms of life were first brought into being in their present form by God at different times over billions of years. \\
\hline Humans-only creationism & $\begin{array}{l}\text { Almost all forms of life evolved from earlier forms, but humans were created by God in their present form separate } \\
\text { from the rest of life. }\end{array}$ \\
\hline Interventionist evolution & All forms of life evolved from earlier forms, but God intervenes from time to time to shape or override evolution. \\
\hline Theistic evolution & $\begin{array}{l}\text { All forms of life evolved from earlier forms, but God set up evolution from the start in a perfect way so that it } \\
\text { would fulfill God's purpose, and no subsequent intervention was necessary. }\end{array}$ \\
\hline Deistic evolution & $\begin{array}{l}\text { All forms of life evolved from earlier forms, but life and evolution were first set in motion by God without a specific } \\
\text { purpose or plan. }\end{array}$ \\
\hline Agnostic evolution & All forms of life evolved from earlier forms, but it is uncertain whether God was involved in evolution. \\
\hline
\end{tabular}

college biology students across this many U.S. states, we decided it would be informative to report them. Therefore, we examined the percentage of students who chose special creationist options for their personal view on religion and evolution and report those percentages.

To examine whether students perceived evolution as atheistic or agnostic, we calculated the percentage of students who chose atheistic evolution and agnostic evolution as the most representative descriptions of evolution.

We were interested in exploring differences among highly religious students who perceived evolution as atheistic versus agnostic. Therefore, we first identified highly religious students as students who more than "agreed" on average (average score $>4.5$ ) with the four religiosity items on the survey. We then analyzed data from these students using multiple linear regression analyses (outcome $\sim$ gender + major + perception of evolution). We did not control for differences in race/ethnicity or religious denomination because of the small number of non-white students and non-Christian students in these analyses (see Table 6 later in this paper). The same model diagnostics were performed on these data as in study 1 (i.e., checking linearity, multicollinearity, and influential points; Kutner et al., 2005). All results we report in the Results sections have passed the full diagnostics.

\section{Study 2 Results}

Sample. Of the $\sim 2649$ students who were sent a survey recruitment message, 1898 students completed the survey demographics $(71.6 \%$ response rate). Response rate by individual course ranged from 37 to $92 \%$ and can be found in Table 3. Of these students, $66.6 \%$ were female, $32.5 \%$ were male, and $0.2 \%$ were nonbinary; $55.4 \%$ were White, $18.1 \%$ were Asian, 8.0\% were Hispanic, 4.4\% were Black/African American, $2.8 \%$ were another race/ethnicity, and $9.7 \%$ were multiracial; $53.0 \%$ of students were biology majors.

\section{Study 2 RQ 1: What Proportion of College Biology Students Accept That Life on Earth Shares a Common Ancestor?}

After they had learned evolution, we found that $29.7 \%$ of students chose a special creationist personal view that God created species separately (Table 4); $25.3 \%$ of students chose a personal view in which they accepted that all of life shares a common ancestor but believed God had some role in evolution (deistic, theistic, or interventionist evolution); $25.4 \%$ of students accepted the common ancestry of life but said it was uncertain whether God was involved in evolution (agnostic evolution). Finally, $19.5 \%$ of students accepted the common ancestry of life and believed that God played no role in evolution (atheistic evolution). See Table 4 for the percentage of students who chose each view on religion and evolution.

\section{Study 2 RQ 2: What Proportion of College Biology Students Think That Evolution Is Atheistic?}

When we examined students' perceptions of whether evolution is atheistic, we found that $56.5 \%$ of all students perceived that evolution is atheistic according to the scientific view and chose "all forms of life evolved from earlier forms, but no God has ever played any role in evolution." Only $30.5 \%$ of all students perceived evolution as agnostic and chose "all forms of life evolved from earlier forms, but it is uncertain whether God was involved in evolution."

We identified 360 students as highly religious, and within this sample of highly religious students, $44.2 \%$ of students perceived evolution as agnostic and $34.7 \%$ of students perceived evolution as atheistic. Table 5 shows a comparison for the percentage of nonreligious and highly religious students who perceived evolution as atheistic or agnostic.

Next, we focus on highly religious students only and compare those who perceived evolution as agnostic with those who perceived evolution as atheistic. Table 6 shows a comparison of the demographics of these students. Highly religious students who perceived evolution as atheistic or agnostic were similar with respect to major, gender, and race, but there was a lower percentage of Church of Jesus Christ of Latter-day Saints (LDS) students who perceived evolution as atheistic and a higher percentage of Catholic and other Christian students who perceived evolution as atheistic. These results for LDS students may be due in part to recent attempts to help LDS college biology students in Utah reduce their conflict between religion and evolution (Manwaring et al., 2015; Bradshaw et al., 2018). 
TABLE 3. Summary of courses recruited and student response rate by course

\begin{tabular}{lllccrr}
\hline Course topic & Course type & Audience & Public/private & Carnegie classification & State & Response rate \\
\hline General biology & Introductory & Nonmajors & Private & Doctoral, R1 & Utah & $137 / 300(46 \%)$ \\
General biology & Introductory & Majors & Private & Doctoral, R1 & Utah & $101 / 120(84 \%)$ \\
General biology & Introductory & Majors & Private & Doctoral, R1 & New York & $431 / 650(66 \%)$ \\
General biology & Introductory & Majors & Public & 2 year & California & $12 / 30(40 \%)$ \\
General biology & Introductory & Majors & Public & 2 year & California & $11 / 30(37 \%)$ \\
Biological anthropology & Introductory & Majors & Public & Master's & Alabama & $15 / 20(75 \%)$ \\
General biology & Introductory & Majors & Public & Doctoral, R1 & Hawaii & $260 / 300(87 \%)$ \\
General biology & Introductory & Majors & Public & Doctoral, R1 & North Carolina $407 / 500(81 \%)$ \\
General biology & Introductory & Majors & Public & Doctoral, R1 & California & $248 / 312(79 \%)$ \\
Genetics & Upper level & Majors & Public & Master's & Alabama & $11 / 12(92 \%)$ \\
Mammalogy & Upper level & Majors & Public & Bachelor's & Wisconsin & $67 / 75(89 \%)$ \\
Evolution & Upper level & Majors & Public & Doctoral, R1 & Arizona & $198 / 300(66 \%)$ \\
\hline
\end{tabular}

\section{Study 2 RQ 3: Do Highly Religious Students Accept Evolution Less, Perceive More Conflict between Their Religious Beliefs and Evolution, and Experience More Discomfort when They Think Evolution Is Atheistic?}

Controlling for gender and major, we found that highly religious students who thought evolution is atheistic had lower microevolution acceptance scores $(\beta=-0.142, p=0.017)$, lower macroevolution acceptance scores $(\beta=-0.157, p=$ $0.007)$, lower human evolution acceptance scores $(\beta=-0.180$, $p=0.002$ ), and lower self-defined evolution acceptance scores ( $\beta=-0.176, p=0.003$ ) than highly religious students who thought evolution was agnostic (Figure 2a-d). All F-statistics for each regression were statistically significant $(p>0.05)$. Full regression tables with all omnibus statistics for each regression are available in Section 5 of the Supplemental Material.

Controlling for gender and major, we also found that highly religious students who perceived evolution as atheistic were less comfortable learning evolution than highly religious students who perceived that evolution is agnostic $(\beta=-0.186, p=$ 0.002 ; Figure $2 \mathrm{e}$ ). Further, highly religious students who perceived that evolution is atheistic perceived more conflict between their religious beliefs and evolution than highly religious students who perceived evolution as agnostic $(\beta=0.262$, $p<0.001$; Figure 2f).

The impact of religious students' perception of evolution on their affective evolution education outcome measures was most apparent when examining those who had the lowest scores

TABLE 4. Undergraduate biology students' personal views on religion and evolution $(n=1898)$

\begin{tabular}{lc}
\hline & $\%(n)$ \\
\hline Accepts common ancestry: & $70.0(1333)$ \\
Atheistic evolution & $19.5(371)$ \\
Agnostic evolution & $25.4(482)$ \\
Deistic evolution & $6.7(127)$ \\
Theistic evolution & $15.0(285)$ \\
Interventionist evolution & $3.6(68)$ \\
Rejects common ancestry: & $30.0(565)$ \\
Human creationism & $5.6(107)$ \\
Creationism with some evolution & $12.5(237)$ \\
Old Earth creationism & $5.9(112)$ \\
Young Earth creationism & $5.7(109)$ \\
\hline
\end{tabular}

(Figure 2a-f). For instance, among the religious students who perceived evolution as agnostic, the most uncomfortable students were only "slightly uncomfortable" while learning evolution. However, among highly religious students who perceived evolution as atheistic, the most uncomfortable students were "very uncomfortable" learning evolution.

\section{Study 2 Conclusions}

In study 2, we found that, even after learning about evolution in college, approximately $30 \%$ of students did not accept the common ancestry of life. We also found that $56.5 \%$ of students thought that the most accurate description of evolution was one in which evolution makes claims about the nonexistence of a God. When exploring differences in student scores between highly religious students who perceived evolution as atheistic and highly religious students who perceived evolution as agnostic, we found that highly religious students who thought evolution is atheistic were less accepting of evolution by all measures compared with highly religious students who thought evolution is agnostic. Further, highly religious students who perceived evolution as atheistic perceived more conflict between their religious beliefs and evolution and felt less comfortable learning evolution compared with highly religious students who perceived evolution as agnostic.

TABLE 5. Student perceptions of the definition of evolution ${ }^{\mathrm{a}}$

\begin{tabular}{|c|c|c|}
\hline & $\begin{array}{c}\frac{\text { Nonreligious }}{\text { students }} \\
n=719 \\
\%(n)\end{array}$ & $\begin{array}{c}\text { Highly religious } \\
\begin{array}{c}\text { students } \\
n=360 \\
\%(n)\end{array}\end{array}$ \\
\hline Agnostic evolution & $24.3(175)$ & 44.2 (159) \\
\hline Atheistic evolution & $72.2(519)$ & $34.7(125)$ \\
\hline Deistic evolution & $1.0(7)$ & $3.1(11)$ \\
\hline Theistic evolution & $1.0(7)$ & $8.6(31)$ \\
\hline Interventionist evolution & $0.0(0)$ & $1.1(4)$ \\
\hline Human creationism & $0.3(2)$ & $0.8(3)$ \\
\hline Creationism with some evolution & $0.8(6)$ & 3.9 (14) \\
\hline Old Earth creationism & $0.0(0)$ & $0.8(3)$ \\
\hline Young Earth creationism & $0.4(3)$ & $2.8(1)$ \\
\hline
\end{tabular}

aHighly religious students are students who, on average, more than "agreed" with survey items measuring religiosity, and nonreligious students are students who on average "disagreed." 
TABLE 6. Comparison of the major, gender, religious denomination, and race/ethnicity of highly religious students who perceived evolution as atheistic and highly religious students who perceived evolution as agnostic $(n=283)$

\begin{tabular}{|c|c|c|}
\hline & $\begin{array}{c}\text { Agnostic } \\
\text { perception } \\
\%(n)\end{array}$ & $\begin{array}{c}\text { Atheistic } \\
\text { perception } \\
\%(n)\end{array}$ \\
\hline \multicolumn{3}{|l|}{ Major } \\
\hline Biology major & $57.9(70)$ & $42.1(51)$ \\
\hline Nonmajor & $54.9(89)$ & $45.1(73)$ \\
\hline \multicolumn{3}{|l|}{ Gender } \\
\hline Female & $55.9(100)$ & $44.1(79)$ \\
\hline Male & $56.7(59)$ & $43.3(45)$ \\
\hline \multicolumn{3}{|l|}{ Religious denomination } \\
\hline Christian: Catholic & $41.2(14)$ & $58.8(20)$ \\
\hline Christian: LDS ${ }^{a}$ & $66.5(105)$ & $33.5(53)$ \\
\hline Christian: Protestant & $43.0(34)$ & $57.0(45)$ \\
\hline Other religion $^{\mathrm{b}}$ & $50.0(6)$ & $50.0(6)$ \\
\hline \multicolumn{3}{|l|}{ Race/ethnicity } \\
\hline Asian & $43.3(13)$ & $56.7(17)$ \\
\hline Black/African American & $35.7(5)$ & $64.3(9)$ \\
\hline Latinx & $40.0(4)$ & $60.0(6)$ \\
\hline White/European American & $58.1(118)$ & $41.9(85)$ \\
\hline More than one/other race & 73.1 (19) & $26.9(7)$ \\
\hline
\end{tabular}

aLDS, Church of Jesus Christ of Latter-day Saints.

'Includes Hindu; Jewish; Buddhist; Christian, Orthodox; Christian, nondenominational; and Muslim.

\section{DISCUSSION, POTENTIAL LIMITATIONS, AND FUTURE RESEARCH}

These results, in tandem with prior literature, suggest that college biology instructors may be able to support highly religious student evolution acceptance by explicitly describing that evolution does not disprove the existence of supernatural entities. In other words, teaching the bounded nature of science in the context of evolution by describing evolution as agnostic rather than atheistic. While prior literature suggests that religiosity and evolution acceptance are related due to specific religious beliefs that are incompatible with evolution (Scott, 2005; Winslow et al., 2011; Barnes et al., 2020), our study suggests that evolution acceptance and religiosity are also related because students perceive that evolution is atheistic.

However, our methodology for this study does not allow us to make claims about the causality of the relationships we studied. Further, we did not test the impact of changing students' perceptions of evolution from atheistic to agnostic, so we cannot say what the magnitude of that impact would be. However, student self-reports in interview studies suggest that helping students understand that evolution is agnostic may increase their evolution acceptance (Winslow et al., 2011; Barnes, et al., 2017b), and leaders in evolution education have self-reported in essays that teaching the bounded nature of science while teaching evolution has led to positive impacts on their students' evolution acceptance (Smith, 1994; Southerland and Scharmann, 2013; Scharmann, 2018; Nelson et al., 2019). The practical significance of this study is to illuminate that more a
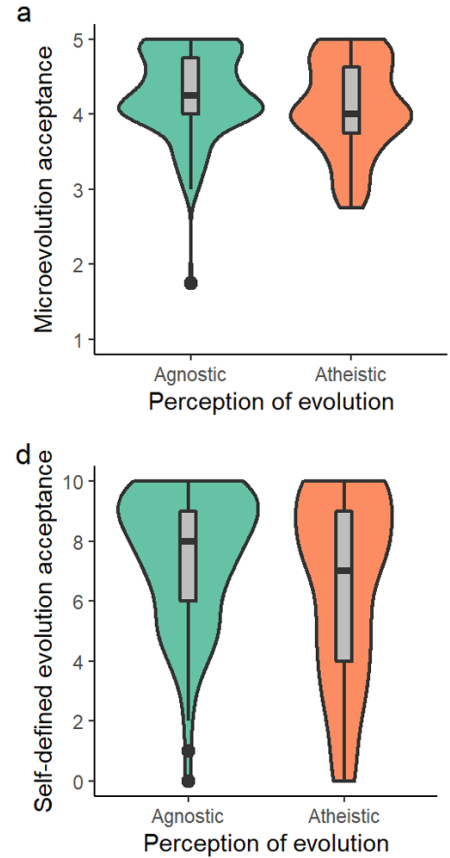

b

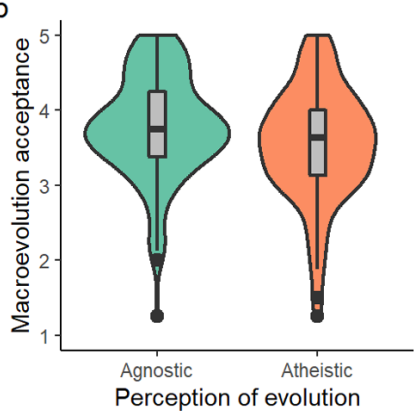

e

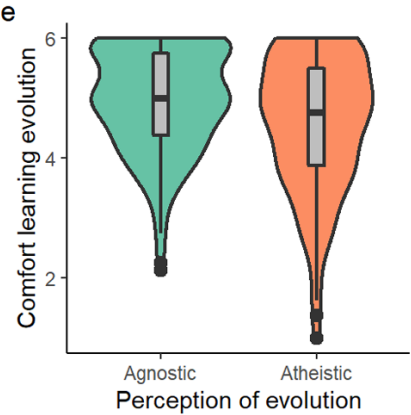

C

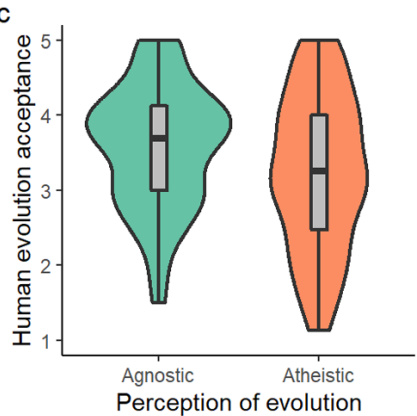

Perception of evolution Agnostic Atheistic

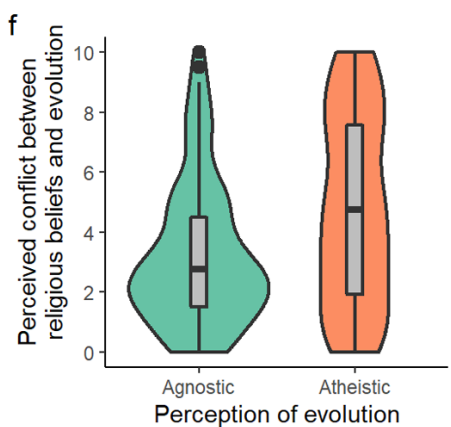

FIGURE 2. Highly religious student evolution acceptance $(a-d)$, comfort learning evolution (e), and perceived conflict (f) between religious beliefs and evolution disaggregated by highly religious students who thought evolution is atheistic (atheistic perception) and highly religious students who thought evolution is agnostic (agnostic perception). Higher scores represent higher evolution acceptance (a-d), more comfort learning evolution (e), and more perceived conflict (f). Violins show the distribution of the data; the gray bar in the middle of each violin indicates the interquartile range; the black line in the middle of each bar indicates the median; the black lines extending from each bar indicate first/third quartile \pm 1.5 interquartile range. 
than half of college biology students perceive that evolution is atheistic, which is concerning, because it is a potentially inaccurate conception that could lead to religious students' rejection of evolution and other poor evolution education experiences. Our results build on the prior literature and confirm that the conception that evolution is atheistic is prevalent among students and statistically significantly related to lower evolution acceptance among religious students. Together, this body of research and experience from evolution educators suggests that instructors can increase evolution acceptance among religious students by explicitly teaching them that evolutionary theory is agnostic rather than atheistic. The magnitude of this effect should be explored in future research.

Our results also highlight the importance of examining religious students separately from nonreligious students in evolution education. Because religious students have a set of worldviews that can create barriers to evolution acceptance that are not present for nonreligious students, relationships between variables and evolution acceptance will likely be different for religious and nonreligious students. Although recent evolution education studies have probed the interactions between religiosity and other variables when studying evolution acceptance (Weisberg et al., 2018), such research is still uncommon. Many studies do not collect or report students' religiosity (i.e., Mead et al., 2018; Metzger et al., 2018; Pobiner et al., 2018). However, our results build on the growing body of literature that suggests this should become a common part of any protocol in which researchers are measuring evolution acceptance.

Given these results and prior literature, we encourage biology instructors to think about how their own personal views of evolution and religion may affect how they communicate with students about whether evolution is atheistic or agnostic. Seventy-five percent of biologists nationwide do not believe in a God (Ecklund and Scheitle, 2007; Pew, 2009), so presumably these biologists hold the personal view of atheistic evolution. However, do biologists who hold an atheistic personal view of evolution recognize and communicate to their students the bounded nature of science? It is likely that instructors who do not have personal religious backgrounds themselves do not think or teach about this distinction in the context of evolution (Barnes and Brownell, 2016, 2018), because the culture of science is generally seen as more compatible with atheism than theism (Ecklund and Park, 2009). However, our data suggest that whether an instructor recognizes and communicates the bounded nature of science accurately during evolution instruction could matter for religious student outcomes in evolution education. For these reasons, we encourage instructors to familiarize themselves with Religious Cultural Competence in Evolution Education (Barnes and Brownell, 2017), an umbrella framework of instructional practices identified in the literature to help nonreligious instructors better understand how to teach religious students about evolution in an effective and culturally competent way, which includes teaching the bounded nature of science (Barnes et al., 2017b).

We operated on an assumption about the nature of science that supernatural existence or influence is outside the scope of science. However, still a small number of biologists claim that because evolutionary theory operates on the assumption that a God is not needed for evolution to occur, this means that evolution does indeed claim that God was not involved in evolution and/or does not exist (Coyne, 2015; Dawkins, 2009). We agree that evolution operates from the assumption that a God is not needed for evolution to occur, but do not agree that this is incompatible with a personal belief that a God does exist and has somehow influenced evolution. Researchers in evolution education have discussed and advocated for this distinction between methodological naturalism and philosophical naturalism in the evolution education literature (Scott, 2005; Sober, 2011). A thorough treatment of this nuanced distinction is outside the scope of this paper, but for an overview see "Nature of Science" (Scott, 2005, chap. 13).

We chose to aggregate scores from Likert-type response options to create continuous Likert scales and used parametric statistics in our analyses. As argued by Norman (2010), this issue has two parts: measurement and statistics. The conclusions from the parametric statistics are valid as long as the assumptions of the data distributions are roughly met. Substantial literature exists to show that parametric statistics are robust, giving the right answers even when assumptions are violated. In the Results sections of this paper, we have demonstrated that the assumptions linear regression has on data distributions are roughly met, which justifies the use of the parametric statistics methods on the data. However, we would like to acknowledge the controversy in the measurement part. In our study, we followed a commonly accepted practice of summing individual items scores to form the score of the scale and use the summed score to represent the latent construct. We agree with the opponents of this practice that single Likert response format items are on an ordinal scale, but the proponents of this practice argue that many studies have shown that Likert scales (as opposed to single items) produce interval data appropriate for parametric statistics (e.g., Carifio and Perla, 2007). As a further direction, one may consider applying item response theory (Hambleton et al., 1991) to extract measurement of the latent constructs.

\section{CONCLUSION}

We found that $56.5 \%$ of college biology students in our sample perceived that evolution is atheistic. Further, we found that having this perception predicted lower levels of evolution acceptance and comfort learning evolution as well as higher perceived conflict between religious beliefs and evolution among highly religious students. If the associations documented here are found to be causally related, then college biology instructors could increase evolution acceptance by teaching students that evolution does not disprove the existence of a God/god(s).

\section{ACKNOWLEDGMENTS}

We would like to acknowledge Jim Collins for his feedback on earlier versions of the article as well as members of the Biology Education Research lab at Arizona State University for their feedback. This project was supported by National Science Foundation grants IUSE 1818659, IUSE 1712188, and DGE-1311230.

\section{REFERENCES}

American Association for the Advancement in Science. (2011). Vision and change in undergraduate biology education: A call to action. Washington, DC.

Barbour, I. G. (1990). Religion in an age of science. San Francisco: Harper \& Row. 
Barnes, M. E., \& Brownell, S. E. (2016). Practices and perspectives of college instructors on addressing religious beliefs when teaching evolution. CBE-Life Sciences Education, 15(2), 1-19. https://doi.org/10.1187/ cbe.15-11-0243

Barnes, M. E., \& Brownell, S. E. (2017). A call to use cultural competence when teaching evolution to religious college students: Introducing Religious Cultural Competence in Evolution Education (ReCCEE). CBE-Life Sciences Education, 16(4), es4. https://doi.org/10.1187/cbe.17-04-0062

Barnes, M. E., \& Brownell, S. E. (2018). Experiences and practices of evolution instructors at Christian universities that can inform culturally competent evolution education. Science Education, 102(1), 36-59. https://doi .org/10.1002/sce.21317

Barnes, M. E., Dunlop, H. M., Holt, E. A., Zheng, Y., \& Brownell, S. E. (2019). Different evolution acceptance instruments lead to different research findings. Evolution: Education and Outreach, 12(1), 4. https://doi .org/10.1186/s12052-019-0096-z

Barnes, M. E., Elser, J., \& Brownell, S. E. (2017). Impact of a Short Evolution Module on Students' Perceived Conflict between Religion and Evolution. American Biology Teacher, 79(2), 104-111. https://doi.org/10.1525/ abt.2017.79.2.104

Barnes, M. E., Evans, E. M., Hazel, A., Brownell, S. E., \& Nesse, R. M. (2017a). Teleological reasoning, not acceptance of evolution, impacts students ability to learn natural selection. Evolution: Education and Outreach, 10 7. https://doi.org/10.1186/s12052-017-0070-6

Barnes, M. E., Truong, J. M., \& Brownell, S. E. (2017b). Experiences of Judeo-Christian students in undergraduate biology. CBE-Life Sciences Education, 16(1), ar15. https://doi.org/10.1187/cbe.16-04-0153

Barnes, M. E., Werner, R., \& Brownell, S. E. (2020). Differential impacts of a culturally competent genetics curriculum on student perceptions of conflict between religion and evolution at an evangelical Christian university. American Biology Teacher, 82(2), 93-101. https://doi.org/ 10.1525/abt.2020.82.2.93

Barnes, R. M., Keilholtz, L. E., \& Alberstadt, A. L. (2008). Creationism and evolution beliefs among college students. Skeptic, 14(3), 13-16.

Bishop, B. A., \& Anderson, C. W. (1990). Student conceptions of natural selection and its role in evolution. Journal of Research in Science Teaching, 27(5), 415-427. https://doi.org/10.1002/tea.3660270503

Bradshaw, W. S., Phillips, A. J., Bybee, S. M., Gill, R. A., Peck, S. L., \& Jensen, J. L. (2018). A longitudinal study of attitudes toward evolution among undergraduates who are members of the Church of Jesus Christ of Latter-day Saints. PLOS ONE, 13(11), e0205798. https://doi.org/10.1371/ journal.pone.0205798

Brem, S. K., Ranney, M., \& Schindel, J. (2003). Perceived consequences of evolution: College students perceive negative personal and social impact in evolutionary theory. Science Education, 87(2), 181-206. https:// doi.org/10.1002/sce.10105

Brownell, S. E., Freeman, S., Wenderoth, M. P., \& Crowe, A. J. (2014). BioCore Guide: A tool for interpreting the core concepts of Vision and Change for biology majors. CBE-Life Sciences Education, 13(2), 200-211. https:// doi.org/10.1187/cbe.13-12-0233

Carifio, J., \& Perla, R. J. (2007). Ten common misunderstandings, misconceptions, persistent myths and urban legends about Likert scales and Likert response formats and their antidotes. Journal of Social Sciences, 3(3), 106-116.

Cho, J. Y., \& Lee, E.-H. (2014). Reducing confusion about grounded theory and qualitative content analysis: Similarities and differences. The Qualitative Report, 19(32), 1.

Cohen, A. B., Shariff, A. F., \& Hill, P. C. (2008). The accessibility of religious beliefs. Journal of Research in Personality, 42(6), 1408-1417. https://doi .org/10.1016/j.jp.2008.06.001

Collins, F. S. (2006). The language of God: A scientist presents evidence for belief. New York: Simon and Schuster.

Coyne, J. A. (2015). Faith versus fact: Why science and religion are incompatible. New York: Penguin.

Dawkins, R. (2009). The god delusion. New York: Random House.

Dingemans, E., \& Van Ingen, E. (2015). Does religion breed trust? A cross-national study of the effects of religious involvement, religious faith, and religious context on social trust. Journal for the Scientific Study of Religion, 54(4), 739-755. https://doi.org/10.1111/jssr.12217
Dunk, R. D. P., Petto, A. J., Wiles, J. R., \& Campbell, B. C. (2017). A multifactorial analysis of acceptance of evolution. Evolution: Education and Outreach, 10, 4. https://doi.org/10.1186/s12052-017-0068-0

Ecklund, E. H., \& Park, J. Z. (2009). Conflict between religion and science among academic scientists? Journal for the Scientific Study of Religion, 48(2), 276-292. https://doi.org/10.1111/j.1468-5906.2009.01447.x

Ecklund, E. H., Park, J. Z., \& Sorrell, K. L. (2011). Scientists negotiate boundaries between religion and science. Journal for the Scientific Study of Religion, 50(3), 552-569. https://doi.org/10.1111/j.1468-5906.2011.01586.x

Ecklund, E. H., \& Scheitle, C. P. (2007). Religion among academic scientists: Distinctions, disciplines, and demographics. Social Problems, 54(2), 289-307. https://doi.org/10.1525/sp.2007.54.2.289

Ecklund, E. H., Scheitle, C. P., \& Peifer, J. (2018). The religiosity of academic scientists in the United Kingdom: Assessing the role of discipline and department status. Journal for the Scientific Study of Religion, 57(4), 743757. https://doi.org/10.1111/jssr.12552

Eddy, S. L., Brownell, S. E., Thummaphan, P., Lan, M. C., \& Wenderoth, M. P. (2015). Caution, student experience may vary: Social identities impact a student's experience in peer discussions. CBE-Life Sciences Education, 14(4), ar45.

Eignor, D. R. (2013). The standards for educational and psychological testing. In Geisinger, K. F., Bracken, B. A., Carlson, J. F., Hansen, J.-I. C., Kuncel, N. R., Reise, S. P., \& Rodriguez, M. C. (Eds.), APA handbook of testing and assessment in psychology, Vol. 1, Test theory and testing and assessment in industrial and organizational psychology (pp. 245-250). Washington, DC American Psychological Association. https://doi.org/10.1037/14047-013

Gallup. (2019). 40\% of Americans believe in creationism. Retrieved August 31 2019, from https://news.gallup.com/poll/261680/americans-believe-creationism.aspx

García, A. A. (2011). Cognitive interviews to test and refine questionnaires. Public Health Nursing, 28(5), 444-450. https://doi.org/10.1111/ j.1525-1446.2010.00938.x

Glaze, A. L., Goldston, M. J., \& Dantzler, J. (2014). Evolution in the southeastern USA: Factors Influencing acceptance and rejection in pre-service science teachers. International Journal of Science and Mathematics Education, 13(6), 1189-1209. https://doi.org/10.1007/ s10763-014-9541-1

Gould, S. J. (2011). Rocks of ages: Science and religion in the fullness of life. New York: Random House Publishing Group.

Ha, M., Haury, D. L., \& Nehm, R. H. (2012). Feeling of certainty: Uncovering a missing link between knowledge and acceptance of evolution. Journal of Research in Science Teaching, 49(1), 95-121. https://doi.org/10.1002/ tea.20449

Hambleton, R. K., Swaminathan, H., \& Rogers, H. J. (1991). Fundamentals of item response theory. Newbury Park, CA: Sage.

Harris, S. (2005). The end of faith: Religion, terror, and the future of reason New York: Norton

Hermann, R. S. (2012). Cognitive apartheid: On the manner in which high school students understand evolution without believing in evolution. Evolution: Education and Outreach, 5(4), 619-628. https://doi .org/10.1007/s12052-012-0446-6

Hill, J. P. (2014). Rejecting evolution: The role of religion, education, and social networks. Journal for the Scientific Study of Religion, 53(3), 575-594. https://doi.org/10.1111/jssr.12127

Huxley, T. H. (1884). Agnosticism: A symposium. The Agnostic Annual. Retrieved May 26, 2019, from https://mathcs.clarku.edu/huxley/UnColl/ Rdetc/AgnAnn.html

Huxley, T. H., \& Huxley, L. (1900). Life and letters of Thomas Henry Huxley (Vol. 1). London: Macmillan.

Ingram, E. L., \& Nelson, C. E. (2006). Relationship between achievement and students' acceptance of evolution or creation in an upper-level evolution course. Journal of Research in Science Teaching, 43(1), 7-24. https://doi. org/10.1002/tea.20093

Kahan, D. M., \& Stanovich, K. E. (2016). Rationality and belief in human evolution (SSRN scholarly paper no. ID 2838668). Retrieved August 31, 2019, from https://papers.ssrn.com/abstract=2838668

Krauss, L. (2015, September 8). All scientists should be militant atheists. Retrieved May 19, 2017, from www.newyorker.com/news/news-desk/ all-scientists-should-be-militant-atheists 
Kutner, M. H., Nachtsheim, C. J., Neter, J., \& Li, W. (2005). Applied linear statistical models (Vol. 5). New York: McGraw-Hill Irwin.

Landis, J. R., \& Koch, G. G. (1977). The measurement of observer agreement for categorical data. Biometrics, 33, 159-174.

Manwaring, K. F., Jensen, J. L., Gill, R. A., \& Bybee, S. M. (2015). Influencing highly religious undergraduate perceptions of evolution: Mormons as a case study. Evolution: Education and Outreach, 8(1), 23. https://doi. org/10.1186/s12052-015-0051-6

Mead, R., Hejmadi, M., \& Hurst, L. D. (2018). Scientific aptitude better explains poor responses to teaching of evolution than psychological conflicts. Nature Ecology \& Evolution, 2(2), 388-394. https://doi.org/10.1038/ s41559-017-0442-x

Metzger, K. J., Montplaisir, D., Haines, D., \& Nickodem, K. (2018). Investigating undergraduate health sciences students' acceptance of evolution using MATE and GAENE. Evolution: Education and Outreach, 11(1), 10. https:// doi.org/10.1186/s12052-018-0084-8

Micari, M., \& Drane, D. (2011). Intimidation in small learning groups: The roles of social-comparison concern, comfort, and individual characteristics in student academic outcomes. Active Learning in Higher Education, 12(3), 175-187. https://doi.org/10.1177/1469787411415078

Miller, J. D., Scott, E. C., \& Okamoto, S. (2006). Public acceptance of evolution. Science, 313(5788), 765-766. https://doi.org/10.1126/ science.1126746

Miller, K. R. (1999). Finding Darwin's God: A scientist's search for common ground between God and evolution. New York: Harper-Collins.

Nadelson, L. S., \& Southerland, S. (2012). A more fine-grained measure of students' acceptance of evolution: Development of the Inventory of Student Evolution Acceptance-I-SEA. International Journal of Science Education, 34(11), 1637-1666. https://doi.org/10.1080/09500693.2012.702235

National Academy of Sciences (NAS). (1998). Teaching about evolution and the nature of science. National Academies Press.

NAS. (2008). Science, evolution, and creationism. National Academies Press.

National Science Foundation, National Center for Science and Engineering Statistics. (2017). Women, minorities, and persons with disabilities in science and engineering: 2017 (Special report NSF 17-310). Retrieved August 25, 2019, from www.nsf.gov/statistics/wmpd

Nehm, R. H., Kim, S. Y., \& Sheppard, K. (2009). Academic preparation in biology and advocacy for teaching evolution: Biology versus non-biology teachers. Science Education, 93(6), 1122-1146. https://doi.org/10.1002/ sce. 20340

Nelson, C. E., Scharmann, L. C., Beard, J., \& Flammer, L. I. (2019). The nature of science as a foundation for fostering a better understanding of evolution. Evolution: Education and Outreach, 12(1), 6. https://doi.org/10.1186/ s12052-019-0100-7

Norman, G. (2010). Likert scales, levels of measurement and the "laws" of statistics. Advances in Health Sciences Education, 15(5), 625-632. https://doi.org/10.1007/s10459-010-9222-y

Numbers, R. L. (2006). The creationists: From scientific creationism to intelligent design. Cambridge, MA: Harvard University Press.

Pew. (2009). Scientists and belief. Retrieved March 14, 2016, from www .pewforum.org/2009/11/05/scientists-and-belief

Pew. (2015). America's changing religious landscape. Retrieved October 19, 2015, from www.pewforum.org/2015/05/12/americas-changing-religious -landscape

Pobiner, B., Beardsley, P. M., Bertka, C. M., \& Watson, W. A. (2018). Using human case studies to teach evolution in high school A.P. biology classrooms. Evolution: Education and Outreach, 11(1), 3. https://doi .org/10.1186/s12052-018-0077-7

Popper, K. (1959). The logic of scientific discovery. New York: Hutchinson.

Rissler, L. J., Duncan, S. I., \& Caruso, N. M. (2014). The relative importance of religion and education on university students' views of evolution in the Deep South and state science standards across the United States.
Evolution: Education and Outreach, 7(1), 24. https://doi.org/10.1186/ s12052-014-0024-1

Rutledge, M. L., \& Warden, M. A. (1999). The development and validation of the measure of acceptance of the theory of evolution instrument. School Science and Mathematics, 99(1), 13-18. https://doi.org/10.1111/ j.1949-8594.1999.tb17441.x

Saad, L. (2017). Record few Americans believe Bible is literal word of god Retrieved February 21, 2019, from https://news.gallup.com/poll/210704/ record-few-americans-believe-bible-literal-word-god.aspx

Sbeglia, G. C., \& Nehm, R. H. (2019). Do you see what I-SEA? A Rasch analysis of the psychometric properties of the Inventory of Student Evolution Acceptance. Science Education, 103(2), 287-316. https://doi.org/10.1002/ sce. 21494

Scharmann, L. C. (2018). Evolution and nature of science instruction. Evolution: Education and Outreach, 11(1), 14. https://doi.org/10.1186/s12052 $-018-0088-4$

Scharmann, L. C., \& Butler, W., Jr (2015). The use of journaling to assess student learning and acceptance of evolutionary science. Journal of College Science Teaching, 45(1), 16.

Scott, E. C. (2005). Evolution vs. creationism: An introduction. Berkeley: University of California Press. Retrieved from https://books.google .com/books?hl=en\&lr=\&id=03b_aOmonNYC\&oi=fnd\&pg=PR9\&dq =evolution+and+creation+an+introductiongots=YsGsqL1qMG\&sig =P14SdVOpThaTSSIcmR1BkCerIWE

Sinatra, G. M., Southerland, S. A., McConaughy, F., \& Demastes, J. W. (2003) Intentions and beliefs in students' understanding and acceptance of biological evolution. Journal of Research in Science Teaching, 40(5), 510 528. https://doi.org/10.1002/tea.10087

Smith, M. U. (1994). Counterpoint: Belief, understanding, and the teaching of evolution. Journal of Research in Science Teaching, 31(5), 591-597. https://doi.org/10.1002/tea.3660310512

Smith, M. U., Snyder, S. W., \& Devereaux, R. S. (2016). The GAENE-Generalized Acceptance of Evolution Evaluation: Development of a new measure of evolution acceptance. Journal of Research in Science Teaching, 53(9), 1289-1315. https://doi.org/10.1002/tea.21328

Sober, E. (2011). Why Methodological Naturalism. Biological Evolution-Facts and Theories: A Critical Appraisal 150 Years after The Origin of Species 359-378.

Southerland, S. A., \& Scharmann, L. C. (2013). Acknowledging the religious beliefs students bring into the science classroom: Using the bounded nature of science. Theory Into Practice, 52(1), 59-65. https://doi.org/10 $1080 / 07351690.2013 .743778$

Tharoor, I. (2014, October 28). Pope Francis says evolution is real and God is no wizard. Washington Post. Retrieved August 31, 2019, from www washingtonpost.com/news/worldviews/wp/2014/10/28/pope-francis -backs-theory-of-evolution-says-god-is-no-wizard

Theobald, E. J., Eddy, S. L., Grunspan, D. Z., Wiggins, B. L., \& Crowe, A. J. (2017). Student perception of group dynamics predicts individual performance: Comfort and equity matter. PLOS ONE, 12(7), e0181336. https:// doi.org/10.1371/journal.pone.0181336

Weisberg, D. S., Landrum, A. R., Metz, S. E., \& Weisberg, M. (2018). No missing link: Knowledge predicts acceptance of evolution in the United States. BioScience, 68(3), 212-222.

Willis, G. B. (2004). Cognitive interviewing: A tool for improving questionnaire design. Newbury Park, CA: Sage.

Winslow, M. W., Staver, J. R., \& Scharmann, L. C. (2011). Evolution and personal religious belief: Christian university biology-related majors' search for reconciliation. Journal of Research in Science Teaching, 48(9), $1026-$ 1049. https://doi.org/10.1002/tea.20417

Yasri, P., \& Mancy, R. (2016). Student positions on the relationship between evolution and creation: What kinds of changes occur and for what reasons? Journal of Research in Science Teaching, 53(3), 384-399. https:// doi.org/10.1002/tea.21302 